\title{
Development, Comparison, and Validation of Real-Time and Conventional PCR Tools for the Detection of the Fungal Pathogens Causing Brown Spot and Red Band Needle Blights of Pine
}

\author{
Renaud Ioos, Bénédicte Fabre, Carole Saurat, Céline Fourrier, Pascal Frey, and Benoît Marçais
}

First, third, and fourth authors: Laboratoire National de la Protection des Végétaux, Station de mycologie, IFR 110, Domaine de Pixérécourt, F-54220 Malzéville, France; and second, fifth, and sixth authors: INRA, Nancy-Université, UMR1136 Interactions Arbres-Microorganismes, IFR 110, F-54280 Champenoux, France.

Accepted for publication 23 September 2009.

\begin{abstract}
Ioos, R., Fabre, B., Saurat, C., Fourrier, C., Frey, P., and Marçais, B. 2010. Development, comparison, and validation of real-time and conventional PCR tools for the detection of the fungal pathogens causing brown spot and red band needle blights of pine. Phytopathology 100:105-114.

Dothistroma pini, D. septosporum, and Lecanosticta acicola are fungal pathogens that cause severe foliage diseases in conifers. All three pathogens are listed as quarantine organisms in numerous countries throughout the world and, thus, are subject to specific monitoring. Detection and identification of these pathogens still often relies on cumbersome and unsatisfactory methods that are based upon the morphological characterization of fungal fruiting bodies and conidia. In this study, we present the development of several new molecular tools that enable a rapid and specific in planta detection of each of these

pathogens. Several DNA extraction procedures starting from infected needles were compared and four commercial DNA extraction kits provided DNA of satisfactory quality for amplification by polymerase chain reaction (PCR). In addition, we developed several sets of conventional PCR primers, dual-labeled probes (DLPs), and duplex-scorpion probes (DSPs), all of which targeted each pathogen. Their ability to detect the pathogens in a series of naturally infected needle samples was compared. The quadruplex DLP real-time assay proved to be more sensitive than the DSP assay and conventional PCR but the two real-time probe formats yielded identical results in the naturally infected samples. Both real-time assays proved to be significantly superior to the technique of humid chamber incubation, which often failed to produce spores for the accurate identification of the pathogens.
\end{abstract}

Brown spot needle blight and red band needle blight of pine are serious diseases that affect conifers. The first disease is caused by the ascomycete Mycosphaerella dearnessii M. E. Barr while the second is caused by two cryptic deuteromycete species, Dothistroma septosporum (Dorog.) M. Morelet (teleomorph M. pini Rostr.) and D. pini (teleomorph unknown).

$M$. dearnessii can be easily identified by microscopic observation of the typical conidiospores of the anamorph stage, (i.e., Lecanosticta acicola (Thüm.) Syd.), which are produced in the conidiomata developing on the infected needles $(4,8)$. The two species, D. pini and D. septosporum, were recently split by Barnes et al. (4) based mainly on morphology and sequence analysis of three nuclear genes. D. pini and D. septosporum can hardly be distinguished by the morphology of their conidiospores, and identification of the two species based only on observation of microscopic features is judged to be almost impossible (4).

Difficulties in pathogen identification may arise when the conidiomata observed on the host tissue fail to produce mature conidia even after incubation in a humid chamber, which is a recommended method (8). In addition, isolation of $L$. acicola, $D$. pini, and D. septosporum for identification also is often difficult and time consuming, because these fungi grow very slowly and are easily out-competed by fast-growing saprotrophic or endophytic fungi $(8,9)$.

L. acicola, D. pini, and D. septosporum are listed as quarantine fungi for the European Union (2), and they are subjected to

Corresponding author: R. Ioos; E-mail address: renaud.ioos@ agriculture.gouv.fr

doi:10.1094/PHYTO-100-1-0105

(c) 2010 The American Phytopathological Society specific surveys and phytosanitary controls. Reliable enforcement of such monitoring depends on the application of rapid, specific, and sensitive detection tools. The availability of molecular-based detection tools would greatly help overcome the problem of identification of these three pathogens on their host. Because $L$. acicola, D. pini, and D. septosporum share similar host trees and may display similar symptoms on late observation, a molecular tool that enables simultaneous detection of all three pathogens would make it possible to speed up the analytical process and would provide more comprehensive data about the actual distribution of these pathogens in different parts of the world.

Previous studies have shown that the sequences of the $\beta$-tubulin 2 ( $\beta$-tub2) and translation elongation factor $(\mathrm{EF} 1-\alpha)$ genes may be suitable to differentiate $L$. acicola, D. septosporum, and D. pini (4) because they displayed significant interspecific intronic polymorphism.

The aims of this present work were to (i) develop molecular tools to be used in either conventional or real-time polymerase chain reaction (qPCR) formats, including a quadruplex assay, for the direct and simultaneous in planta detection of $L$. acicola, $D$. pini, and D. septosporum; (ii) compare the efficiency of several DNA extraction procedures starting from naturally infected pine needles, with or without mature conidiomata; and (iii) assess the efficiency of these new tools on a large set of naturally infected samples.

\section{MATERIALS AND METHODS}

Fungal isolates and pine needle samples. Fungal isolates used in this study, consisting of Dothistroma spp., L. acicola, and other fungi commonly found on pine needles (Table 1), were isolated 
from pine needles collected mainly in France in naturally infected stands using the method described by Barnes et al. (4), for which the needle samples are first frozen at $-70^{\circ} \mathrm{C}$ before plating out the spores from the conidiomata. Fungi were cultured with constant shaking in potato dextrose broth (PDB) (Difco, Beckton, Dickinson and Co., Sparks, MD) for 2 to 3 weeks, after which 50 to 200 $\mathrm{mg}$ of fresh mycelium was harvested and transferred into a 2-ml tube. Total DNA was extracted using the DNeasy plant mini kit (Qiagen, Hilden, Germany) following the manufacturer's instructions. DNA concentrations were estimated using a UV spectrophotometer (BioPhotometer; Eppendorf, Le Pecq, France).

Symptomatic pine needles were collected in 2007 and 2008 by the staff of the French forest health service (Département de la Santé des Forêts) in pine stands infected by Dothistroma spp. or L. acicola across France. Immediately after collection, each sample was packed individually and stored at $5 \pm 3^{\circ} \mathrm{C}$ before processing. Each needle sample consisted of several hundred needles collected from 1 to 3 symptomatic pine trees from each location.

Design of primers, dual-labeled probes, and duplex-scorpion probes. The $\beta$-tub2 and $E F 1-\alpha$ sequences were obtained using previously described primers $(7,10)$ with a series of six $L$. acicola, five $D$. septosporum, and five $D$. pini isolates of additional geographical origins and were deposited in GenBank (Table 1).

For the two genes, all the available sequences retrieved from GenBank, including isolates from different continents, were then analyzed and compared by multiple alignments, which included orthologous sequences from phylogenetically close species with Mycosphaerella spp. as teleomorph, using CLUSTALW (online access: http://npsa-pbil.ibcp.fr/cgi-bin/npsa_automat.pl?page=/ NPSA/npsa_clustalwan.html). A series of forward and reverse primer and probe combinations specific for each of the three fungi were manually designed from several polymorphic regions. Their respective melting temperatures (Tm) and potential secondary structures were evaluated in silico using Beacon Designer software (Premier Biosoft, Palo Alto, CA) in order to select suitable forward and reverse primer combinations. Primers were also designed to amplify very short PCR fragments, because longer fragments may lead to a loss of sensitivity in multiplex reactions, when compared to separate PCR reactions (16). These forward and reverse primers were then evaluated in vitro by realtime PCR with SYBR-green intercalating dye to assess their sensitivity and their proneness to self- or interhybridization. The primers were tested with DNA extracted from a pure culture of $D$. pini (Dp294), D. septosporum (Ds293), and L. acicola (Md15).

For each the three pathogens, the primers with the lowest tendency to form secondary structures were then retained for further development of conventional PCR or real-time PCR tools. Retained primers and probes also fulfilled the technical and thermodynamic requirements for a primer/dual-labeled probe (DLP) combination for real-time PCR according to Bustin (6). Their sequence and the reporter/quencher dye combination for the DLPs are indicated in Table 2. A universal primer pair (18S uni-

TABLE 1. Characteristics of the fungal isolates and sequences used in this study

\begin{tabular}{|c|c|c|c|c|c|c|c|}
\hline \multirow[b]{2}{*}{ Organism } & \multirow[b]{2}{*}{ Isolate } & \multirow[b]{2}{*}{ Host } & \multirow[b]{2}{*}{ Year } & \multirow[b]{2}{*}{ Origin } & \multicolumn{2}{|c|}{ GenBank accession number } & \multirow[b]{2}{*}{ Reference } \\
\hline & & & & & $\mathrm{EF} 1-\alpha$ & $\beta$-tub2 & \\
\hline \multirow[t]{14}{*}{ Dothistroma pini } & Dp294a & Pinus nigra & 1995 & France (Pyrénées Atlantiques) & FJ467318 & FJ467302 & This study \\
\hline & Dp9-12 & P. nigra & 2007 & France (Ariège) & FJ467321 & FJ467305 & This study \\
\hline & Dp6-19 & P. nigra & 2007 & France (Ariège) & FJ467320 & FJ467304 & This study \\
\hline & Dp13-2 & P. nigra & 2007 & France (Pyrénées Atlantiques) & $\ldots$ & $\ldots$ & This study \\
\hline & Dp3-7 & P. nigra & 2007 & France (Pyrénées Atlantiques) & FJ467319 & FJ467303 & This study \\
\hline & $\mathrm{C} 15^{\mathrm{b}}$ & P. nigra & 2007 & France (Corrèze) & FJ467322 & FJ467306 & This study \\
\hline & CMW6400 & P. nigra & $\ldots$ & United States (Michigan) & AY808271 & AY808236 & 4 \\
\hline & CMW14821 & P. nigra & 1964 & United States (Nebraska) & AY808270 & AY808235 & 4 \\
\hline & CMW14820 & P. nigra & 1970 & United States (Minnesota) & AY808269 & AY808234 & 4 \\
\hline & CMW14905 & P. nigra & 2001 & United States (Michigan) & AY808268 & AY808233 & 4 \\
\hline & CMW10951 & P. nigra & 2001 & United States (Michigan) & AY808267 & AY808232 & 4 \\
\hline & CMW10930 & P. nigra & 2001 & United States (Michigan) & AY808266 & AY808231 & 4 \\
\hline & CMW23767 & P. pallasiana & 2004 & Ukraine (Kherson) & $\ldots$ & DQ926939 & 5 \\
\hline & CMW24853 & P. pallasiana & 2006 & Russia (Rostov) & $\ldots$ & EF450257 & 5 \\
\hline \multirow[t]{20}{*}{ D. septosporum } & Ds $292^{\mathrm{a}}$ & P. mugo & 1999 & Germany (Bayern) & FJ467316 & FJ467299 & This study \\
\hline & Ds $293^{a}$ & P. sylvestris & 1999 & Germany (Friedhof) & FJ467317 & FJ467300 & This study \\
\hline & Dsbel $^{\mathrm{c}}$ & P. nigra & 2007 & Belgium (Meeuwen-Gruitrode) & FJ467313 & FJ467301 & This study \\
\hline & Ds $1-2^{b}$ & P. nigra & 2007 & France (Somme) & FJ467314 & FJ467297 & This study \\
\hline & $\mathrm{C} 14^{\mathrm{b}}$ & P. nigra & 2007 & France (Corrèze) & FJ467315 & FJ467298 & This study \\
\hline & CMW14822 & P. ponderosa & 1983 & United States (Oregon) & AY808265 & AY808230 & 4 \\
\hline & CMW15077 & P. ponderosa & 2004 & United States (Idaho) & AY808264 & AY808229 & 4 \\
\hline & CMW14823 & P. contorta var. latifolia & 1997 & Canada (BC) & AY808263 & AY808228 & 4 \\
\hline & CMW14904 & P. nigra & 2004 & Austria (Thenneberg) & AY808262 & AY808227 & 4 \\
\hline & CMW14903 & P. nigra & 2004 & Austria (Vienna) & AY808261 & AY808226 & 4 \\
\hline & CMW13122 & P. mugo & $\ldots$ & Germany (Bavarian Alpes) & AY808260 & AY808225 & 4 \\
\hline & CMW13123 & P. sylvestris & $\ldots$ & Slovakia & AY808259 & AY808224 & 4 \\
\hline & CMW13010 & P. nigra & 2003 & Poland (Krakow) & AY 808258 & AY808223 & 4 \\
\hline & CMW13007 & P. nigra & 2003 & Poland (Krakow) & AY808257 & AY808222 & 4 \\
\hline & CMW13004 & P. nigra & 2003 & Poland (Krakow) & AY808256 & AY808221 & 4 \\
\hline & CMW9992 & P. coulteri & $\ldots$ & France (Meurthe et Moselle) & AY808255 & AY808220 & 4 \\
\hline & CMW9920 & Pinus sp. & 2001 & Ecuador (Lasso highlands) & AY808254 & AY808219 & 4 \\
\hline & CMW8611 & $P$. radiata & 2001 & Chile (Valdivia) & AY808253 & AY808218 & 4 \\
\hline & CMW9304 & P. radiata & 2001 & Chile (Valdivia) & AY808252 & AY808217 & 4 \\
\hline & CMW10247 & $P$. radiata & 2001 & Chile (Bio Bio) & AY808251 & AY808216 & 4 \\
\hline
\end{tabular}

a Isolate provided by Dr. Schumacher and Dr. Pehl, JKI.

b Isolate collected from pine needle and provided by B. Fabre, INRA.

${ }^{c}$ Isolate provided by S. Inghelbrecht, ILVO.

${ }^{\mathrm{d}}$ Isolate provided by C. Saurat and P. Chandelier, LNPV.

${ }^{\mathrm{e}}$ Isolate provided by C. Affeltranger, USFS. 
F/-R) and a DLP (18S uni-P) were also used in this study to target a region of the $18 \mathrm{~S}$ ribosomal rDNA that is highly conserved throughout a wide range of eukaryotic organisms, including plants and fungi. These primers and probe were selected in order to check the quality of the DNA extracted from any plant or fungal sample and to detect false-negative results that could potentially be caused by inhibition or DNA shearing (14). The reporting dyes were selected to have distinctive fluorescence emission wavelengths in order to avoid any overlapping fluorescence spectra, which makes their simultaneous use in a single PCR tube possible.

For D. pini and D. septosporum, specific duplex-scorpion probes (DSPs) were designed to target the same loci as for the respective DLP, based upon the technical recommendations of Solinas et al. (19). Scorpion folding was previously assessed using the mfold program (http://frontend.bioinfo.rpi.edu/applications/mfold/cgi-bin/dna-form1.cgi; DNA mfold server: 19962009, Michael Zuker, Rensselaer Polytechnic Institute). Each of the DSPs was used in real-time PCR with an appropriately designed reverse PCR primer (Table 2).

All primers and probes were custom synthesized by Eurogentec (Seraing, Belgium).

Conventional and real-time PCR conditions. PCR and realtime PCR conditions were optimized in order to maximize sensitivity and specificity. The following conditions were used in all subsequent PCR assays.

The conventional PCR reactions were carried out on a GenAmp 9700 thermocycler (Applied Biosystems, Foster City, CA) in 20- $\mu$ l reaction volumes. The composition of the reaction mixture was $1 \times$ reaction buffer (Hotgoldstar PCR buffer; Eurogentec), $2 \mathrm{mM}$ $\mathrm{MgCl}_{2}, 4 \times 0.2 \mathrm{mM}$ dNTPs, $0.4 \mu \mathrm{M}$ each of the forward and reverse primers, $0.5 \mathrm{U}$ of Hotgoldstar (Eurogentec), $2 \mu \mathrm{l}$ of template DNA ( 0.8 to $20 \mathrm{ng}$ ), and molecular-grade water to $20 \mu \mathrm{l}$. The cycling conditions included an initial denaturation step at $95^{\circ} \mathrm{C}$ for $10 \mathrm{~min}$; followed by 35 cycles of denaturation at $95^{\circ} \mathrm{C}$ for $30 \mathrm{~s}$, annealing at $60^{\circ} \mathrm{C}$ for $30 \mathrm{~s}$, and elongation at $72^{\circ} \mathrm{C}$ for $60 \mathrm{~s}$; and a final extension at $72^{\circ} \mathrm{C}$ for $10 \mathrm{~min}$.

All real-time PCR reactions were performed with a Rotor-Gene 6500 (Corbett Research, Mortlake, Australia) set with an autogain optimization for each channel that was performed before the first fluorescence acquisition. The cycle threshold $(\mathrm{Ct})$ value for each reaction was determined using the Rotor-Gene software version 1.7.75, setting the threshold line $10 \times$ above the mean baseline fluorescence level. Each DNA sample was tested in triplicate and a standard deviation was computed.

For quadruplex DLP real-time assays, the master mix contained equal concentrations of the respective forward and reverse primers, probes for each of the three pathogens, and the probe for the 18S rDNA target. Real-time PCR was carried out in $20-\mu 1$ reaction volumes using the qPCR core kit No ROX (Eurogentec). The reaction mixture contained molecular-grade water, $1 \times$ reaction buffer, $5 \mathrm{mM} \mathrm{MgCl} 2,4 \times 0.2 \mathrm{mM}$ dNTPs, $0.3 \mu \mathrm{M}$ each of the four respective forward and reverse primers, $0.1 \mu \mathrm{M}$ each of the four respective DLPs, $0.5 \mathrm{U}$ of Hotgoldstar, and $2 \mu \mathrm{l}$ of template DNA (0.8 to $20 \mathrm{ng})$. The real-time PCR cycling conditions for

TABLE 1. (continued from preceding page)

\begin{tabular}{|c|c|c|c|c|c|c|c|}
\hline \multirow[b]{2}{*}{ Organism } & \multirow[b]{2}{*}{ Isolate } & \multirow[b]{2}{*}{ Host } & \multirow[b]{2}{*}{ Year } & \multirow[b]{2}{*}{ Origin } & \multicolumn{2}{|c|}{ GenBank accession number } & \multirow[b]{2}{*}{ Reference } \\
\hline & & & & & $\mathrm{EF} 1-\alpha$ & $\beta$-tub2 & \\
\hline & CMW6846 & Pinus sp. & 2001 & Australia (Canberra) & AY808250 & AY808215 & 4 \\
\hline & CMW6845 & Pinus sp. & 2000 & Australia (Canberra) & AY808249 & AY808214 & 4 \\
\hline & CMW6841 & Pinus sp. & 2000 & Australia (Canberra) & AY808248 & AY808213 & 4 \\
\hline & CMW9943 & $P$. radiata & 2002 & New Zealand (Rotorua) & AY808247 & AY808212 & 4 \\
\hline & CMW9939 & $P$. radiata & 2001 & New Zealand (Rotorua) & AY808246 & AY808211 & 4 \\
\hline & CMW9937 & P. contorta & 2001 & New Zealand (Karioi) & AY808245 & AY808210 & 4 \\
\hline & CMW10722 & $P$. radiata & 2002 & Kenya (Napkoi) & AY808244 & AY808209 & 4 \\
\hline & CMW10622 & $P$. radiata & 2002 & Kenya (Napkoi) & AY808243 & AY808208 & 4 \\
\hline & CMW11372 & P. radiata & 2002 & South Africa (Tzaneen) & AY808242 & AY808207 & 4 \\
\hline & CMW8658 & $P$. radiata & 2001 & South Africa (Hogsback) & AY808241 & AY808206 & 4 \\
\hline & CMW684 & $P$. radiata & 1984 & South Africa (Hogsback) & AY808240 & AY808205 & 4 \\
\hline & CMW23765 & P. peuce & 2004 & Austria (Vienna) & $\ldots$ & DQ926925 & 5 \\
\hline & CMW23903 & P. mugo & 2005 & Hungary (Sopron) & $\ldots$ & DQ926931 & 5 \\
\hline & CMW23429 & $P$. radiata & 2005 & Bhutan (Yusipang) & $\ldots$ & DQ926936 & 5 \\
\hline & CMW23901 & P. wallichiana & 2005 & Bhutan (Lamey Goemba) & $\ldots$ & DQ926916 & 5 \\
\hline \multirow[t]{8}{*}{ Lecanosticta acicola } & $\operatorname{Md} 14^{\mathrm{d}}$ & P. muricata & 1995 & France (Gironde) & FJ467323 & FJ467312 & This study \\
\hline & $\operatorname{Md} 15^{\mathrm{d}}$ & $P$. radiata & 1995 & France (Pyrénées Atlantiques) & FJ467324 & FJ467307 & This study \\
\hline & $\operatorname{Md} 16^{\mathrm{e}}$ & P. palustris & 1995 & United States (Louisiana) & FJ467325 & FJ467311 & This study \\
\hline & $\operatorname{Md} 17^{d}$ & Pinus sp. & 1995 & France (Pyrénées Atlantiques) & FJ467326 & FJ467310 & This study \\
\hline & $\operatorname{Md} 8^{\mathrm{d}}$ & $P$. radiata & 1994 & France (Pyrénées Atlantiques) & FJ467327 & FJ467308 & This study \\
\hline & $\operatorname{Md} 9^{d}$ & P. attenuata $\times$ radiata & 1995 & France (Landes) & FJ467328 & FJ467309 & This study \\
\hline & CMW13119 & P. elliottii & $\ldots$ & China (Fujie) & AY808273 & AY808238 & 4 \\
\hline & CMW9985 & $P$. radiata & 1995 & France (Gironde) & AY808272 & AY808237 & 4 \\
\hline Acremonium sp. & $\mathrm{C} 12^{\mathrm{b}}$ & P. nigra & 2007 & France & $\ldots$ & $\ldots$ & This study \\
\hline Basidiomycete & $\mathrm{C} 13^{\mathrm{b}}$ & P. nigra & 2007 & France & $\ldots$ & $\ldots$ & This study \\
\hline Botrytis sp. & $08-386 b^{d}$ & P. nigra & 2008 & France & $\ldots$ & $\ldots$ & This study \\
\hline Coniothyrium sp. & $\mathrm{C} 5^{\mathrm{b}}$ & P. nigra & 2007 & France & $\ldots$ & $\ldots$ & This study \\
\hline Coniothyrium sp. & $\mathrm{C} 9^{\mathrm{b}}$ & P. nigra & 2007 & France & $\ldots$ & $\ldots$ & This study \\
\hline Dematiaceous sterile hyphomycete & $\mathrm{C} 11^{\mathrm{b}}$ & P. nigra & 2007 & France & $\ldots$ & $\ldots$ & This study \\
\hline Epicoccum nigrum & $\mathrm{C} 7^{\mathrm{b}}$ & P. nigra & 2007 & France & $\ldots$ & $\ldots$ & This study \\
\hline Fusarium avenaceum & $8-386^{\mathrm{d}}$ & Pseudotsuga menziesii & 2008 & France & $\ldots$ & $\ldots$ & This study \\
\hline Gliocladium sp. & $\mathrm{C} 2^{\mathrm{b}}$ & Pinus nigra & 2007 & France & $\ldots$ & $\ldots$ & This study \\
\hline Hormonema sp. & $08-452^{\mathrm{d}}$ & Pseudotsuga menziesii & 2008 & France & $\ldots$ & $\ldots$ & This study \\
\hline Leptographium sp. & Lep $^{d}$ & Pinus halepensis & 2008 & France & $\ldots$ & $\ldots$ & This study \\
\hline Leptostroma sp. & $\mathrm{C} 6^{\mathrm{b}}$ & P. nigra & 2007 & France & $\ldots$ & $\ldots$ & This study \\
\hline Leptostroma sp. & $\mathrm{C} 10^{\mathrm{b}}$ & P. nigra & 2007 & France & $\ldots$ & $\ldots$ & This study \\
\hline Libertella sp. & $\mathrm{C} 4^{\mathrm{b}}$ & P. nigra & 2007 & France & $\ldots$ & $\ldots$ & This study \\
\hline Pestalotiopsis sp. & $\mathrm{C} 8^{\mathrm{b}}$ & P. nigra & 2007 & France & $\ldots$ & $\ldots$ & This study \\
\hline Phoma sp. & $\mathrm{C} 1^{\mathrm{b}}$ & P. nigra & 2007 & France & $\ldots$ & $\ldots$ & This study \\
\hline Phomopsis sp. & $08-452^{\mathrm{d}}$ & Pseudotsuga menziesii & 2008 & France & $\ldots$ & $\ldots$ & This study \\
\hline Sirococcus strobilinus & $\mathrm{C} 3^{\mathrm{b}}$ & Pinus nigra & 2007 & France & $\ldots$ & $\ldots$ & This study \\
\hline
\end{tabular}


DLP included an initial denaturation step at $95^{\circ} \mathrm{C}$ for $10 \mathrm{~min}$ followed by 40 cycles of denaturation at $95^{\circ} \mathrm{C}$ for $15 \mathrm{~s}$ and annealing and elongation at $60^{\circ} \mathrm{C}$ for $55 \mathrm{~s}$. For these quadruplex real-time assays, fluorescence for each of the four fluorescent dyes was monitored simultaneously during the reaction. For routine DLP real-time analyses, a bulk ready-to-use quadruplex primer and probe mix was prepared and used in order to make the preparation of master mix easier and to reduce the risks of pipetting errors. This quadruplex primer and probe mix proved to be stable over time, with constant efficiency and sensitivity of the real-time PCR reaction (data not shown).

The DSP PCR reactions were performed in individual tubes for $D$. pini and D. septosporum. Preliminary attempts to simultaneously use the DSP for D. pini and D. septosporum in the same reaction tube resulted in a significant decrease in the experimental sensitivity. DSP PCR reactions were carried out in $20-\mu$ reaction volumes using the qPCR core kit No ROX (Eurogentec). The reaction mixture contained molecular-grade water, $1 \times$ reaction buffer, $5 \mathrm{mM} \mathrm{MgCl} 2,4 \times 0.2 \mathrm{mM}$ dNTPs, $0.5 \mu \mathrm{M}$ reverse primer, $0.5 \mu \mathrm{M}$ specific quenching probe (quenched strand [QS]), $0.1 \mu \mathrm{M}$ specific primer probe (probe-primer strand [PPS]), bovine serum albumin at $0.6 \mu \mathrm{g} \mu \mathrm{l}^{-1}, 0.75 \mathrm{U}$ of Hotgoldstar, and $2 \mu \mathrm{l}$ of template DNA (0.8 to $20 \mathrm{ng}$ ). The real-time PCR cycling conditions for DSP included an initial denaturation step at $95^{\circ} \mathrm{C}$ for $10 \mathrm{~min}$, followed by 40 cycles of denaturation at $95^{\circ} \mathrm{C}$ for $15 \mathrm{~s}$ and annealing and elongation at $55^{\circ} \mathrm{C}$ for $55 \mathrm{~s}$. The fluorescence monitoring temperature during PCR $\left(55^{\circ} \mathrm{C}\right)$ was set well below the estimated Tm of the duplex-scorpion PPS/QS pair in the PCR buffer in order to maintain as low as possible the background fluorescence from the unhybridized duplex scorpion that has not yet been converted to an amplicon (19).

All PCR analyses were carried out using standard procedures to avoid cross-contamination of DNA. No-template controls were systematically included in triplicate to check the absence of contamination in all reactions of conventional or real-time PCR.

Comparison of DNA extraction procedures. Eighty needle subsamples were prepared with needles originating from 27 pine stands infected by either $D$. pini or $D$. septosporum from different locations across France (1 to 13 subsamples per stand). Each subsample consisted of five 5-mm-long needle pieces (23 to $37 \mathrm{mg}$ ) with red band symptoms bearing conidiomata, and was transferred into an individual 2-ml microcentrifuge tube. The comparison of the DNA extraction procedures was conducted with five sets of 16 subsamples (80 subsamples).

Five DNA extraction protocols were tested and compared. They included the DNeasy plant mini kit (Qiagen), the Nucleospin plant II kit (Macherey-Nagel, Düren, Germany), the PureLink Plant Total DNA purification kit (Invitrogen, Carlsbad, CA), the

TABLE 2. Primers, dual-labeled probes, and duplex-scorpion probes designed and tested in this study

\begin{tabular}{|c|c|c|c|c|c|c|}
\hline Target, primer or probe & Sequence $\left(5^{\prime}-3^{\prime}\right)$ & Characteristic $^{\mathrm{a}}$ & $\begin{array}{c}\text { DNA } \\
\text { region }^{b}\end{array}$ & Position $^{c}$ & $\begin{array}{l}\text { Product } \\
\text { size } \\
\text { (bp) }\end{array}$ & $\begin{array}{l}\text { Analytical } \\
\text { sensitivity } \\
(\mathrm{pg})^{\mathrm{d}}\end{array}$ \\
\hline \multicolumn{7}{|l|}{ Dothistroma septosporum } \\
\hline DStub2-F & CGAACATGGACTGAGCAAAAC & Conventional PCR & $\beta$-tub2 & $24-44$ & 231 & 2 \\
\hline DStub2-R & GCACGGCTCTTTCAAATGAC & $\ldots$ & $\ldots$ & $234-254$ & $\ldots$ & $\ldots$ \\
\hline DStub2-F1 & CGAACATGGACTGAGCAAAA & Dual-labeled probe qPCR & $\beta$-tub2 & $24-43$ & 89 & $0.2^{\mathrm{e}}$ \\
\hline DStub2-R1 & TGCCTTCGTATCTGCATTTC & $\ldots$ & $\ldots$ & $92-112$ & $\ldots$ & $\ldots$ \\
\hline DStub2-P1 & ROX-TGGAATCCACAGACGCGTCA-BHQ2f & $\ldots$ & $\ldots$ & $56-76$ & $\ldots$ & $\ldots$ \\
\hline \multirow[t]{2}{*}{ DStub2-PPS1 } & ROX-TGACGCGTCTGTGGATTCCA-HEG- & & & & & \\
\hline & CGAACATGGACTGAGCAAAA ${ }^{\mathrm{g}}$ & Duplex-scorpion qPCR & $\beta$-tub2 & $24-43 / 56-75$ & $89^{\mathrm{h}}$ & 2 \\
\hline DStub2-QS1 & TGGAATCCACAGACGCGTCA-DDQ1 ${ }^{\mathrm{i}}$ & $\ldots$ & $\ldots$ & N/A & $\ldots$ & $\ldots$ \\
\hline DStub2-R2 & TGCCTTCGTATCTGCATTTC & $\ldots$ & $\ldots$ & $92-112$ & $\ldots$ & $\ldots$ \\
\hline \multicolumn{7}{|l|}{ D. pini } \\
\hline DPtef-F & АTTTTTCGCTGCTCGTCACT & Conventional PCR & $\mathrm{EF} 1-\alpha$ & $52-71$ & 193 & 2 \\
\hline DPtef-R & CAATGTGAGATGTTCGTCGTG & & & $224-244$ & & \\
\hline DPtef-F1 & ACAGCAATCACACCCTTGC & Dual-labeled probe $\mathrm{gPCR}$ & $\mathrm{EF} 1-\alpha$ & $178-196$ & 76 & $0.2^{\mathrm{e}}$ \\
\hline DPtef-R1 & TCATGTGCTCAATGTGAGATGT & $\ldots$ & $\ldots$ & $232-253$ & $\ldots$ & $\ldots$ \\
\hline DPtef-P1 & FAM-CCCCAGCCGATTACACGACG-BHQ $1^{j}$ & $\ldots$ & $\ldots$ & $211-231$ & $\ldots$ & $\ldots$ \\
\hline \multirow[t]{2}{*}{ DPtef-PPS1 } & FAM-CGTCGTGTAATCGGCTGGGG-HEG- & & & & & \\
\hline & AATCACACCCTTGCGAAGC & Duplex-scorpion qPCR & EF1- $\alpha$ & $183-201 / 211-230$ & $77^{\mathrm{g}}$ & 2 \\
\hline DPtef-QS1 & CCCCAGCCGATTACACGACG-DDQ1 & $\ldots$ & $\ldots$ & N/A & $\ldots$ & $\ldots$ \\
\hline DPtef-R2 & TCAGAATCATGTGCTCAATGTG & $\ldots$ & $\ldots$ & $238-259$ & $\ldots$ & $\ldots$ \\
\hline \multicolumn{7}{|l|}{ L. acicola } \\
\hline LAtef-F & GCAAATTTTCGCCGTTTATC & Conventional PCR & $\mathrm{EF} 1-\alpha$ & $36-55$ & 237 & 2 \\
\hline LAtef-R & TGTGTTCCAAGAGTGCTTGC & & $\ldots$ & $253-272$ & & \\
\hline LAtef-F1 & ССТССТТСАТСТТССССТТС & Dual-labeled probe qPCR & $\mathrm{EF} 1-\alpha$ & $218-237$ & 79 & $0.2^{\mathrm{j}}$ \\
\hline LAtef-R1 & TGTGGGAGATAGCGTTGTCA & $\ldots$ & $\ldots$ & $277-296$ & $\ldots$ & $\ldots$ \\
\hline LAtef-P1 & Cy5-CAAGCACTCTTGGAACACACCGC-BHQ3 ${ }^{\mathrm{k}}$ & $\ldots$ & $\ldots$ & $254-276$ & $\ldots$ & $\ldots$ \\
\hline \multicolumn{7}{|l|}{ Plant/fungus } \\
\hline $18 \mathrm{~S}$ uni-F & GCAAGGCTGAAACTTAAAGGAA & Dual-labeled probe qPCR & 18S rDNA & N/A & 150 & N/A \\
\hline $18 \mathrm{~S}$ uni-R & CCACCACCCATAGAATCAAGA & $\ldots$ & $\ldots$ & N/A & $\ldots$ & $\ldots$ \\
\hline $18 \mathrm{~S}$ uni-P & JOE-ACGGAAGGGCACCACCAGGAGT-BHQ1 & $\ldots$ & $\ldots$ & N/A & $\ldots$ & $\ldots$ \\
\hline
\end{tabular}

${ }^{\mathrm{a}} \mathrm{qPCR}=$ real-time polymerase chain reaction.

${ }^{\mathrm{b}} \beta$-Tubulin 2 ( $\beta$-tub2); translation elongation factor (EF1- $\left.\alpha\right)$; ribosomal DNA (rDNA).

${ }^{c}$ Position of the primer or probe considering as reference sequences GenBank accessions AY808228, AF808271, and AF808273 for D. septosporum, D. pini, and Lecanosticta acicola, respectively; N/A = not available.

${ }^{\mathrm{d}}$ Quantity of DNA per reaction tube.

${ }^{\mathrm{e}}$ An identical detection threshold was obtained with the primer/probe combination either in separate real-time reaction or in quadruplex real-time reactions (data not shown).

${ }^{\mathrm{f}}$ Black Hole Quencher 2, registered trademark of Biosearch Technologies, Inc.

g Hexa-ethylen glycol (polymerase chain reaction blocker).

${ }^{\text {h }}$ Product size excluding the probe strand upstream the PCR blocker.

i Dark Deep Quencher 1, registered trademark of Eurogentec.

j Black Hole Quencher 1, registered trademark of Biosearch Technologies, Inc.

${ }^{k}$ Black Hole Quencher 3, registered trademark of Biosearch Technologies, Inc. 
BioSprint 96 DNA plant kit used in combination with the BioSprint 96 automated workstation (Qiagen), and a noncommercial DNA extraction procedure using cetyltrimethylammonium bromide (CTAB) as a detergent and phenol-chloroform as organic polar solvents (12). For each of the five procedures, the 16 samples were first ground with the appropriate lysis buffer for $3 \mathrm{~min}$ at $30 \mathrm{~Hz}$ using two 3-mm sterile steel beads in a beadbeater (TissueLyser; Qiagen). Total DNA was further extracted following each corresponding manufacturer's instructions or as described by Henrion et al. (12) for the noncommercial protocol. Total DNA concentrations were estimated using a UV spectrophotometer (BioPhotometer; Eppendorf) and all concentrations were normalized to total DNA at $0.5 \mathrm{ng} \mu \mathrm{l}^{-1}$ per tube.

Two variables were used to compare the five different DNA extraction procedures: the quantity of total DNA extracted from the needle tissue and the mean $\mathrm{Ct}$ value for the detection of the target fungal pathogen, which was either $D$. pini or D. septosporum. A multifactor analysis of variance was performed to evaluate the effect of DNA extraction procedure, with stand location of the sample as covariates, using SAS/STAT 8.1 (SAS Institute, Cary, NC).

Comparative analysis of the detection tools using naturally infected samples. In total, 50 symptomatic needle samples which had yellowing needles with or without conspicuous red band or black spot blight symptoms were analyzed by both classical morphological observation following humid chamber incubation and conventional and real-time PCR. To prevent cross-contaminations between needle samples, the analytical process was organized in the laboratory in order to meet the forward flow requirement. In addition, for each series of DNA extraction, a blank control (sterile water) was systematically processed in parallel to check the absence of contamination during the extraction step. Subsamples from each needle sample were incubated for up to 3 weeks in a humid chamber at $22^{\circ} \mathrm{C}$ with a $12-\mathrm{h}$ light period and then regularly checked for the presence of mature conidiomata bearing typical conidia of either L. acicola, D. pini, or D. septosporum. Given the difficulty in distinguishing $D$. pini from $D$. septosporum based only on conidial morphological features (4), the conidiomata of Dothistroma spp. observed on incubated needles were not assigned to one of the two species. For each sample, five symptomatic 5-mm-long needle pieces were transferred into a sterile 2-ml centrifuge tube and total DNA was extracted using the PureLink Plant Total DNA purification kit, as described above. Each DNA extract was tested in triplicate by conventional and real-time PCR assays.

To assess the ability to detect $D$. pini and D. septosporum on infected needle tissue with red band necrosis but without any conidiomata, 16 additional needle subsamples were prepared and analyzed by multiplex DLP real-time PCR. These 16 subsamples were prepared with needles originating from 11 pine stands across France. Eight subsamples contained needle pieces from pine stands infected with $D$. septosporum and the other eight from pine stands infected with $D$. pini. Presence of each pathogen was previously demonstrated by isolation followed by PCR-restriction fragment length polymorphism (RFLP) (4). Each subsample consisted of five 5-mm-long needle pieces with red band symptoms lacking conidiomata in a sterile 2-ml centrifuge tube. Total DNA was extracted using the PureLink Plant Total DNA purification kit, as described above, and each DNA extract was then tested in triplicate by a multiplex DLP real-time PCR assay.

Assessment of the experimental specificity of conventional and real-time PCR. The specificity of the conventional and realtime PCR tests was assessed with naturally infected needle samples following two approaches. First, isolation of the pathogens was performed as described above on symptomatic needle samples collected from 25 pine stands across France. The isolates obtained were assigned to the species by PCR-RFLP according to Barnes et al. (4). The needle samples were also analyzed with the
DLP real-time PCR test as described above. Second, during the conventional and real-time PCR tests on environmental samples, randomly selected PCR products were sequenced in both directions and compared with reference sequences available on GenBank to check that the amplified sequence corresponded to the expected target.

Repeatability and reproducibility. Repeatability and reproducibility were calculated for the DLP quaduplex assay. Interassay coefficients of variation (CV\% based on mean $\mathrm{Ct}$ values) were assessed for each pathogen with a range of standard DNA samples with low target concentrations and with DNA extracts from a naturally infected sample and from a healthy sample. Interassay CVs were calculated from 10 consecutive assays run over a 4-week period. Intraassay CVs were computed for each pathogen on 10 replicates of the same set of DNA samples tested in the same run. All replicates of DNA extract from healthy samples yielded no $\mathrm{Ct}$ in all 10 consecutive test runs and in the repeatability test.

\section{RESULTS}

Design and evaluation of the PCR primers and real-time PCR probes. Sixteen new partial sequences of the $\beta$-tub2 and EF1- $\alpha$ genes were obtained during this study (Table 1). The DNA regions selected as targets for the primers and probes (Table 2) were $100 \%$ conserved within each of the three studied species. The analytical specificity of all primer and probe combinations was first confirmed by in silico BLAST analyses with all the publicly available DNA sequences deposited in GenBank (Table 1). In vitro specificity tests were further carried out with a series of fungal species occurring in the same ecological niche as the three targeted pathogens (Table 1), as well as with DNA extracted from healthy-looking pine needles that harbor various endophytic mycobiota (18). Both the in silico and in vitro tests confirmed that the primer and probe combinations were specific for their respective fungal target species (D. pini, D. septosporum, or L. acicola) regardless of their geographical origin.

Analytical sensitivity of conventional PCR, DLP, and DSP real-time PCR assays. The dynamic range for each primer/probe combination was assessed with three independent 10 -fold dilution series of D. pini (isolate Dp294), D. septosporum (isolate Ds293), or L. acicola (isolate Md16) genomic DNA in a background of

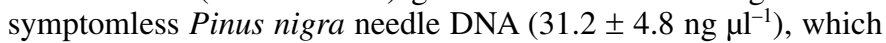

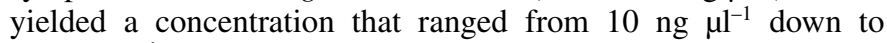
$0.1 \mathrm{pg}^{-1} \mathrm{l}^{-1}$. For quadruplex DLP PCR reactions, as well as for DSP PCR reactions, standard curves showed a linear correlation between input DNA and Ct values (Figs. 1 and 2). Standard curve equation $(y=-3.57 x+22.3$, reaction efficiency $E=90.6 \%)$ and $R^{2}$ coefficient (0.996) for the $18 \mathrm{~S}$ uni test were determined with a serial dilution of $P$. nigra needle DNA ranging from $10 \mathrm{ng}^{-1} \mathrm{l}^{-1}$ to $1 \mathrm{pg} \mu \mathrm{l}^{-1}$.

The analytical sensitivity was the smallest detectable amount of target giving a positive result at least $95 \%$ of the time and was assessed for each pathogen with at least 10 replicates for each concentration level. For D. pini and D. septosporum, the DLP real-time assay was found to be more sensitive than either the DSP real-time assay or the conventional PCR test (Table 2). In addition, similar detection thresholds were obtained for each pathogen with monoplex (a single set of specific primers and probe for one species) or quadruplex (a mix of four primer/DLP combinations) DLP real-time reactions (Table 2).

Inter- and intraassay CVs for the DLP quadruplex assay were low, 0.1 to 1.7 and 0.2 to 1.3 , respectively (Table 3 ).

Comparison of the DNA extraction procedures. No statistical difference was observed between the five DNA extraction procedures in respect with the amount of total DNA $(P=0.212)$ (Table 4). None of the target pathogens could be detected following real-time PCR with the DNA samples obtained by the CTAB- 
based extraction procedure. On the other hand, the detection of Dothistroma spp. was successful with $100 \%$ of the DNA samples obtained with the four commercial DNA extraction kits. Slight but significant differences $(P=0.024)$ were observed between the DNA extraction procedures for the mean $\mathrm{Ct}$ values, with the PureLink Plant Total DNA purification kit (Invitrogen) yielding the lowest value (mean $\mathrm{Ct}=27.9$ ). This kit was retained for the comparison of the detection tools.

Comparative testing of the detection tools with naturally infected needles. Out of the 50 naturally infected samples, 12 were found to be negative by all the techniques used. All 12 samples consisted of yellowing needles without conspicuous red band or brown spot (i.e., without typical symptoms of the studied diseases) (Table 5). Three of those DNA samples did not yield a positive signal with internal transcribed spacer (ITS)1/ITS4 PCR or yielded a $\mathrm{Ct}$ value of $>30$ with $18 \mathrm{~S}$ uni real-time PCR. They were spiked with $2 \mathrm{pg}$ of $D$. septosporum DNA and tested again by the $D$. septosporum conventional and real-time PCR test. Because no positive signal could be obtained with these spiked samples, their DNA was judged to be non- or poorly amplifiable, and these samples were not included in further analysis (Table 5).
On the other hand, nine DNA samples with positive ITS1/ITS4 PCR or yielding a Ct value $<25$ with $18 \mathrm{~S}$ uni real-time PCR but yielding no signal with any of the species-specific conventional and real-time PCR tests were also further spiked with $2 \mathrm{pg}$ of $D$. septosporum DNA and tested again by the D. septosporum conventional and real-time PCR test. For all nine samples, a $D$. septosporum-positive signal was obtained by conventional and real-time PCR, thus showing that their respective DNA extracts were amplifiable and that the target was absent or below the detection threshold of each PCR test (Table 5).

Averaged over the 47 DNA samples, mean $\mathrm{Ct}$ values generated in real-time PCR with the D. septosporum DLP and the D. septosporum DSP, which were $28.3 \pm 3.8$ and $29.1 \pm 2.9$, respectively, were not significantly different $(n=26 ; t=-1.6 ; P=0.054)$. By contrast, the $D$. pini DLP yielded a significantly lower mean $\mathrm{Ct}$ value $(25.8 \pm 3.7)$ than the $D$. pini $\operatorname{DSP}(34.3 \pm 4.1)(n=13 ; t=$ $-11.26 ; P=0.025)$. However, there was a $100 \%$ agreement between the two real-time PCR techniques, because both successfully detected $D$. pini or $D$. septosporum on the same samples $(n=37)$ and yielded negative results for these pathogens with the rest of the samples with amplifiable DNA $(n=10)$.
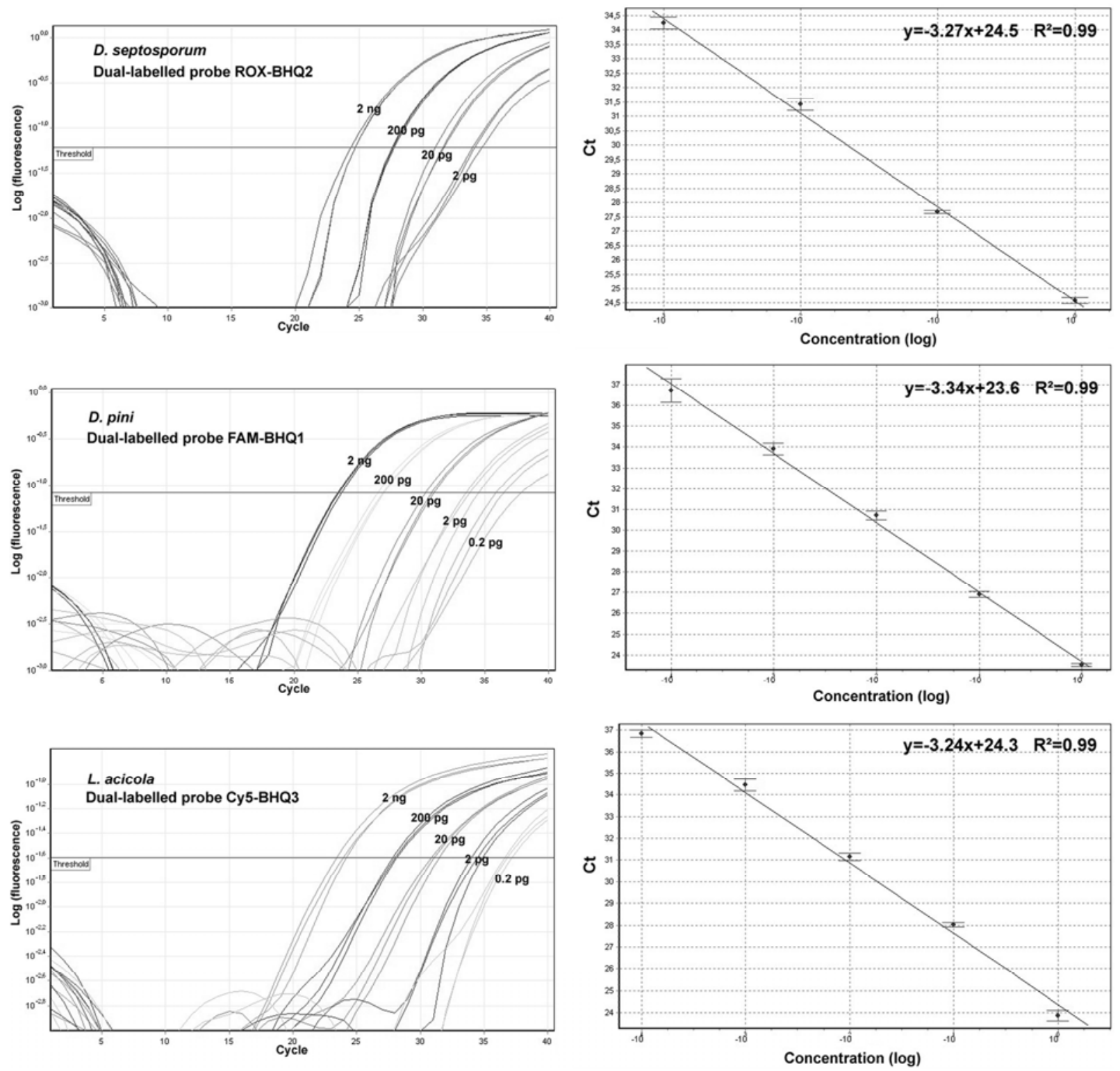

Fig. 1. Log-transformed fluorescence curves, standard curves, and correlation coefficients assessed with dilutions of Dothistroma septosporum, D. pini, and Lecanosticta acicola DNA for quadruplex real-time polymerase chain reaction using the dual-labeled probes DStub2-P1, DPtef-P1, LAtef-P1, and 18S uni-P. Total DNA of the pathogens was diluted in a background of Pinus nigra needle DNA to yield final concentrations that ranged from $1 \mathrm{ng} \mu \mathrm{l}^{-1}$ to $0.1 \mathrm{pg} \mu \mathrm{l}^{-1}$. 
Real-time PCR, conventional PCR, and humid chamber analysis yielded concordant results (positive or negative) in $72.4 \%$ of the samples for D. septosporum or D. pini and $93.7 \%$ of the samples for L. acicola (Table 6). Real-time PCR yielded significantly more positive results than the humid chamber analysis, in particular for Dothistroma spp. $\left(\chi^{2}=6.36, P=0.012\right)$, whereas not enough positive results were recorded for $L$. acicola to support a significant difference between the two tests $\left(\chi^{2}=0.34, P=\right.$ 0.562 ) (Table 6). No significant differences were observed between real-time PCR and conventional PCR regarding the frequency of positive results $\left(\chi^{2}=0.35, P=0.554\right.$ for Dothistroma spp. and $\chi^{2}=$ $0.29, P=0.592$ for $L$. acicola), although positive results were obtained with real-time PCR for DNA samples that were rated as negative (three samples) or nonamplifiable (two samples) following conventional PCR (Table 6). All the samples rated as positive by the humid chamber analysis were confirmed as positive by both the real-time and conventional PCR tests (Table 6).

In addition, the multiplex DLP real-time PCR successfully detected either D. pini or D. septosporum in $100 \%$ of the 16 samples that consisted of needle tissue with red band symptoms but lacking conidiomata. The mean $\mathrm{Ct}$ value of these samples was $27.1 \pm 3.0$ for $D$. pini and $28.2 \pm 3.5$ for $D$. septosporum.

Experimental specificity of the conventional and real-time PCR. A successful isolation of Dothistroma spp. was achieved for only 7 of the 25 needle samples processed. Depending on the needle sample, 1 to 38 isolates could be recovered. All the isolates collected from these seven needle samples could be assigned to one of the two Dothistroma spp. by PCR-RFLP analyses. D. pini was the only species recovered in five needle samples and $D$. septosporum was the only species recovered in two needle samples. Analysis of these needle samples by DLP real-time PCR and by the isolation procedure yielded identical results for six of the seven needle samples (four samples positive for D. pini and two for D. septosporum). In the seventh needle sample, the DLP real-time PCR test indicated that both Dothistroma spp. were present whereas only $D$. pini could be isolated.
The real-time PCR products obtained with 2 samples of each series of 16 needle samples used for the comparison of DNA extraction procedures were sequenced and the sequences deposited in GenBank (accessions FJ868557 to FJ868564). Additionally, 26 conventional and 31 real-time PCR products were sequenced for 22 naturally infected samples used for the compari-

TABLE 3. Inter- and intra-assay coefficients of variation (CV) based on mean cycle threshold values calculated for the dual-labeled probe quadruplex assay

\begin{tabular}{lcc}
\hline & \multicolumn{2}{c}{$\mathrm{CV}(\%)$} \\
\cline { 2 - 3 } Species, target concentration $\left(\mathrm{pg} \mathrm{\mu l}^{-1}\right)^{\mathrm{a}}$ & Intraassay & Interassay \\
\hline Dothistroma pini & 0.2 & 0.1 \\
1,000 & 0.6 & 1.1 \\
100 & 0.9 & 1.0 \\
10 & 1.2 & 1.1 \\
1 & 0.5 & 0.6 \\
n.d. & & \\
D. septosporum & 0.7 & 0.3 \\
1,000 & 0.6 & 0.5 \\
100 & 1.0 & 1.4 \\
10 & 1.1 & 1.5 \\
1 & 1.0 & 1.3 \\
n.d. & & \\
Lecanosticta acicola & 0.4 & 0.6 \\
1,000 & 0.7 & 1.0 \\
100 & 1.1 & 1.5 \\
10 & 1.3 & 1.7 \\
1 & 0.9 & 1.4 \\
n.d. & & \\
\hline
\end{tabular}

${ }^{a}$ Otherwise indicated, consisting of genomic target fungal DNA diluted in a background of Pinus nigra needle DNA; n.d. = not determined.

b Total DNA extract from a D. pini naturally infected sample (08-202) randomly selected among those listed in Table 5.

c Total DNA extract from a D. septosporum naturally infected sample (08203-2) randomly selected among those listed in Table 5.

d DNA extract from a $L$. acicola naturally infected sample (08-1174) randomly selected among those listed in Table 5.
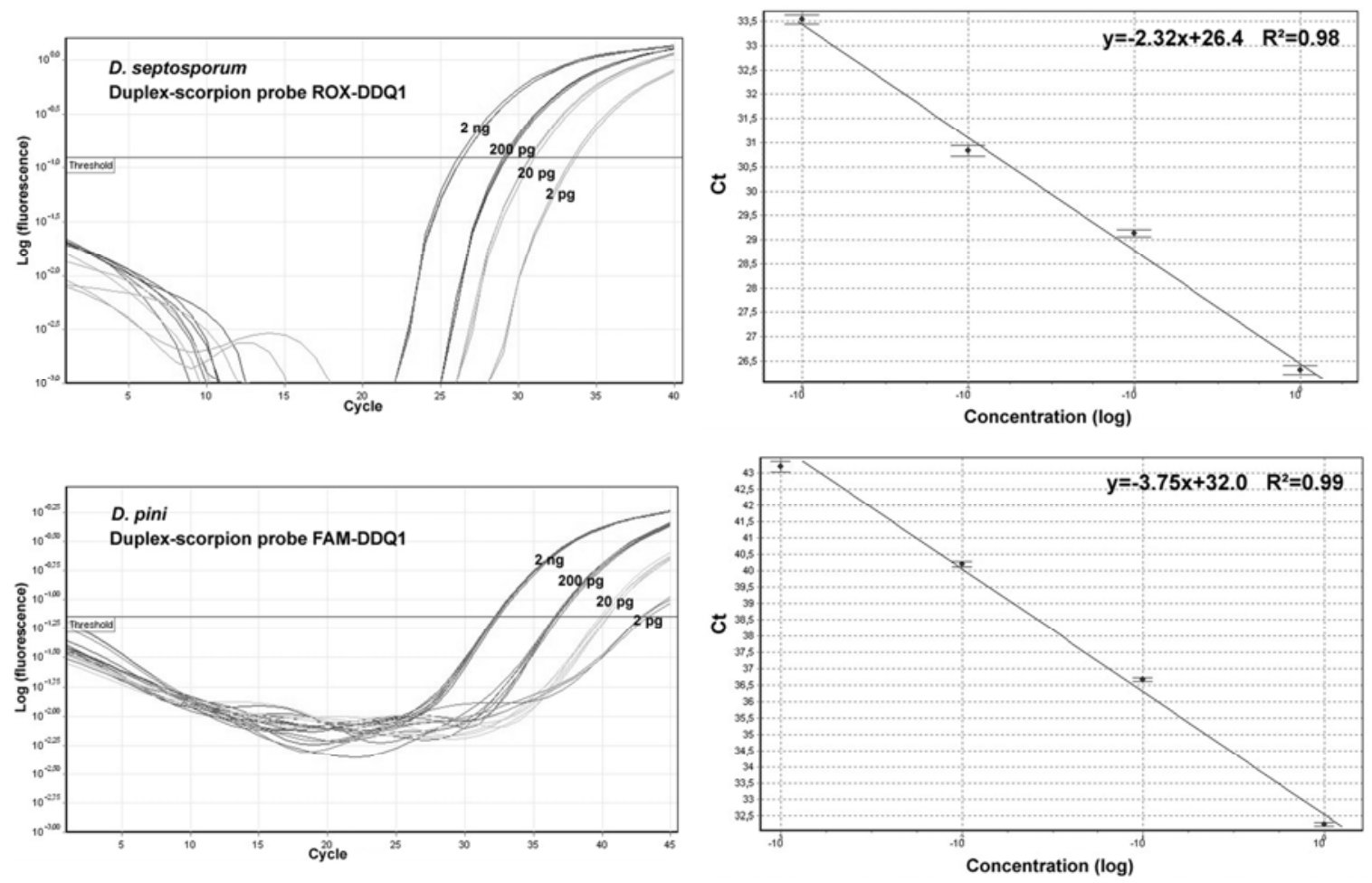

Fig. 2. Log-transformed fluorescence curves, standard curves, and correlation coefficients assessed with dilutions of Dothistroma septosporum and D. pini for real-time polymerase chain reaction using the duplex-scorpion probes DStub2-PPS1/-QS1 and DPtef-PPS1/-QS1. Total DNA of the pathogens was diluted in a background of Pinus nigra needle DNA to yield final concentrations that ranged from $1 \mathrm{ng}^{\mathrm{l}^{-1}}$ to $0.1 \mathrm{pg} \mathrm{\mu l}^{-1}$. 
TABLE 4. Quantity of total DNA in the needle extract and the mean cycle threshold $(\mathrm{Ct})$ value for each of the five DNA extraction procedures

\begin{tabular}{|c|c|c|}
\hline DNA extraction procedure ${ }^{a}$ & Total DNA in five needle pieces with red band necrosis (ng) & Mean $\mathrm{Ct}$ value \\
\hline CTAB buffer/phenol-chloroform & $1,076.0(735.0-1417.1)$ & $>40$ \\
\hline DNeasy plant mini kit (Qiagen) & $662.7(339.6-985.8)$ & $28.5(27.7-29.3)$ y \\
\hline Nucleospin plant II (Macherey-Nagel) & $843.8(596.3-1091.3)$ & $28.7(27.9-29.5) \mathrm{yz}$ \\
\hline PureLink Plant Total DNA purification kit (Invitrogen) & $719.2(440.8-997.7)$ & $27.9(27.1-28.7) \mathrm{y}$ \\
\hline BioSprint 96 DNA plant kit (Qiagen) & $496.8(163.9-829.7)$ & $29.8(29.0-30.5) \mathrm{z}$ \\
\hline
\end{tabular}

a $\mathrm{CTAB}=$ cetyltrimethylammonium bromide.

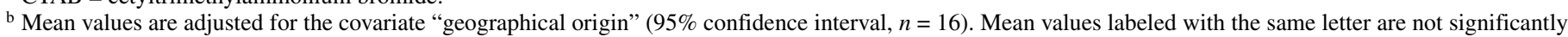
different according to $t$ test pairwise comparison $(P>0.05)$.

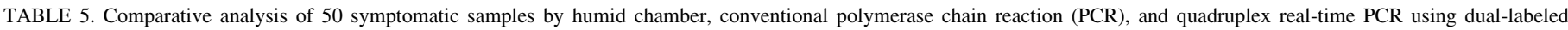
probes, targeting Dothistroma septosporum, D. pini, and Lecanosticta acicola

\begin{tabular}{|c|c|c|c|c|c|c|c|c|c|c|c|}
\hline \multirow[b]{3}{*}{ Sample } & \multirow[b]{3}{*}{ Symptoms ${ }^{\mathrm{a}}$} & \multirow[b]{3}{*}{ Origin } & \multirow[b]{3}{*}{ Humid chamber ${ }^{b}$} & \multicolumn{8}{|c|}{ Conventional PCR/quadruplex real-time $\mathrm{PCR}^{\mathrm{c}}$} \\
\hline & & & & \multicolumn{2}{|c|}{ L. acicola } & \multicolumn{2}{|c|}{ D. septosporum } & \multicolumn{2}{|c|}{ D. pini } & \multicolumn{2}{|c|}{ DNA quality } \\
\hline & & & & $\begin{array}{l}\text { LAtef } \\
-F /-R\end{array}$ & $\begin{array}{c}\text { LAtef } \\
\text {-F1/-R1/-P1 }\end{array}$ & $\begin{array}{l}\text { DStub2 } \\
- \text { F/-R }\end{array}$ & $\begin{array}{c}\text { DStub2 } \\
\text {-F1/-R1/-P1 }\end{array}$ & $\begin{array}{l}\text { DPtef } \\
-F /-R\end{array}$ & $\begin{array}{c}\text { DPtef } \\
-\mathrm{F} 1 /-\mathrm{R} 1 /-\mathrm{P} 1\end{array}$ & $\begin{array}{l}\text { ITS1/ } \\
\text { ITS4 }^{d}\end{array}$ & $\begin{array}{l}18 \mathrm{~S} \text { uni } \\
-\mathrm{F} /-\mathrm{R} / \mathrm{-P}\end{array}$ \\
\hline $08-159$ & $\mathrm{YN}+\mathrm{RB}+\mathrm{Pyc}$ & Eure & Dothistroma sp. & - & $>40$ & $+^{\mathrm{e}}$ & $27.0(0.3)^{\mathrm{e}}$ & $+^{\mathrm{e}}$ & $26.6(0.3)^{\mathrm{e}}$ & + & $17.9(0.2)$ \\
\hline $08-178 \mathrm{a}$ & $\mathrm{YN}+\mathrm{RB}+\mathrm{Pyc}$ & Indre & Dothistroma sp. & - & $>40$ & $+^{\mathrm{e}}$ & $24.7(0.1)^{\mathrm{e}}$ & $t^{\mathrm{e}}$ & $19.9(0.2)^{\mathrm{e}}$ & + & $17.6(0.3)$ \\
\hline $08-178 b$ & $\mathrm{YN}+\mathrm{RB}+\mathrm{Pyc}$ & Indre & Dothistroma sp. & - & $>40$ & - & $>40$ & $+^{e}$ & $21.1(0.1)^{\mathrm{e}}$ & + & $16.5(0.1)$ \\
\hline 08-179 & YN + RB + Pyc. & Indre & Dothistroma sp. & - & $>40$ & $+^{e}$ & $20.8(0.1)^{\mathrm{e}}$ & $+^{e}$ & $24.1(0.1)^{\mathrm{e}}$ & + & $17.0(0.2)$ \\
\hline 08-197-1 & $\mathrm{YN}$ & Finistère & Neg. & - & $>40$ & $+^{e}$ & $26.2(0.4)^{\mathrm{e}}$ & - & $>40$ & + & $19.5(0.2)$ \\
\hline 08-197-2 & $\mathrm{YN}+\mathrm{RB}+$ Pyc. & Loiret & Dothistroma sp. & - & $>40$ & - & $>40$ & $+^{\mathrm{e}}$ & $22.9(0.1)^{\mathrm{e}}$ & + & $17.2(0.1)$ \\
\hline 08-201 & $\mathrm{YN}+\mathrm{RB}+$ Pyc. & Loiret & Dothistroma sp. & - & $>40$ & - & $>40$ & + & $24.1(0.0)$ & + & $19.2(0.0)$ \\
\hline 08-202 & $\mathrm{YN}+\mathrm{BS}$ & Morbihan & Neg. & - & $>40$ & - & $>40$ & - & $22.7(0.5)^{\mathrm{e}}$ & + & $18.1(0.0)$ \\
\hline 08-203-1 & $\mathrm{YN}+\mathrm{RB}+$ Pyc. & Allier & Dothistroma sp. & - & $>40$ & - & $>40$ & + & $30.3(0.1)$ & + & $18.5(0.2)$ \\
\hline $08-203-2$ & $\mathrm{YN}+\mathrm{RB}+$ Pyc. & Allier & Dothistroma sp. & - & $>40$ & $+^{e}$ & $30.9(0.7)^{\mathrm{e}}$ & $+^{\mathrm{e}}$ & $31.0(0.5)^{\mathrm{e}}$ & + & $19.8(0.5)$ \\
\hline $08-215$ & YN + RB + Pyc. & Loir et Cher & Dothistroma sp. & - & $>40$ & - & $>40$ & $+^{\mathrm{e}}$ & $28.2(0.4)^{\mathrm{e}}$ & + & $18.1(0.1)$ \\
\hline 08-233-1 & $\mathrm{YN}$ & Cantal & Neg. & n.a. & n.a. & n.a. & n.a. & n.a. & n.a. & - & $>40$ \\
\hline $08-233-2$ & $\mathrm{YN}+\mathrm{RB}$ & Cantal & Neg. & - & $>40$ & + & $26.5(0.1)$ & - & $>40$ & + & $20.8(0.1)$ \\
\hline $08-234$ & YN & Cantal & Neg. & n.a. & n.a. & n.a. & n.a. & n.a. & n.a. & - & $>40$ \\
\hline 08-244-1 & $\mathrm{YN}+\mathrm{RB}+$ Pyc. & Eure & Dothistroma sp. & - & $>40$ & + & $26.5(0.1)$ & - & $>40$ & + & $20.7(0.2)$ \\
\hline $08-244-2$ & $\mathrm{YN}+\mathrm{RB}+$ Pyc. & Eure & Dothistroma sp. & n.a. & $>40$ & n.a. & $32.4(0.8)$ & n.a. & $>40$ & - & $20.8(0.1)$ \\
\hline $08-451-1$ & $\mathrm{YN}+\mathrm{BS}+$ Pyc. & Ariège & L. acicola & $+^{e}$ & $26.2(0.2)^{\mathrm{e}}$ & $+^{e}$ & $27.2(0.1)^{\mathrm{e}}$ & - & $>40$ & + & $24.0(0.2)$ \\
\hline $08-451-2$ & $\mathrm{YN}+\mathrm{BS}+$ Pyc. & Ariège & L. acicola & n.a. & $27.8(0.3)^{\mathrm{e}}$ & n.a. & $36.9(1.8)^{\mathrm{e}}$ & n.a. & $>40$ & - & $18.6(0.2)$ \\
\hline $08-528-1$ & $\mathrm{YN}+\mathrm{RB}+$ Pyc. & Loir et Cher & Dothistroma sp. & - & $>40$ & + & $28.3(0.1)$ & - & $>40$ & + & $19.9(0.1)$ \\
\hline $08-528-2$ & $\mathrm{YN}+\mathrm{RB}$ & Indre et Loire & Neg. & - & $>40$ & + & $29.4(0.0)$ & - & $>40$ & + & $18.4(0.1)$ \\
\hline $08-553$ & $\mathrm{YN}+\mathrm{BS}$ & Marne & Neg. & n.a. & n.a. & n.a. & n.a. & n.a. & n.a. & - & $33.3(0.5)$ \\
\hline $08-560-1$ & $\mathrm{YN}+\mathrm{RB}+$ Pyc. & Eure & Neg. & - & $>40$ & + & $26.8(0.2)$ & - & $>40$ & + & $16.1(0.0)$ \\
\hline $08-560-2$ & $\mathrm{YN}+\mathrm{RB}+$ Pyc. & Eure & Dothistroma sp. & - & $>40$ & + & $29.9(0.3)$ & - & $>40$ & + & $18.9(0.2)$ \\
\hline $08-560-3$ & $\mathrm{YN}+\mathrm{RB}+$ Pyc. & Eure & Dothistroma sp. & - & $>40$ & + & $25.9(0.1)$ & - & $>40$ & + & $18.5(0.0)$ \\
\hline $08-560-4$ & $\mathrm{YN}+\mathrm{RB}+$ Pyc. & Eure & Dothistroma sp. & - & $>40$ & + & $27.5(0.0)$ & - & $>40$ & + & $20.4(0.1)$ \\
\hline $08-674$ & $\mathrm{YN}+\mathrm{RB}+$ Pyc. & Seine Maritime & Dothistroma sp. & - & $>40$ & + & $24.5(0.1)$ & - & $>40$ & + & $16.8(0.1)$ \\
\hline 08-764-1 & $\mathrm{YN}$ & Ariège & Neg. & - & $>40$ & - & $>40$ & - & $>40$ & + & $17.5(0.1)$ \\
\hline $08-764-2$ & $\mathrm{YN}$ & Ariège & Neg. & - & $>40$ & - & $>40$ & - & $>40$ & + & $16.3(0.3)$ \\
\hline $08-764-3$ & YN & Ariège & Neg. & - & $>40$ & - & $>40$ & - & $>40$ & + & $18.8(0.4)$ \\
\hline $08-764-4$ & $\mathrm{YN}+\mathrm{BS}$ & Ariège & Neg. & $+^{\mathrm{e}}$ & $33.8(0.8)^{\mathrm{e}}$ & $+^{e}$ & $36.9(1.0)^{\mathrm{e}}$ & - & $>40$ & + & $13.8(0.2)$ \\
\hline 08-764-1' & YN & Ariège & Neg. & - & $>40$ & - & $>40$ & - & $>40$ & + & $17.9(0.2)$ \\
\hline 08-764-2' & $\mathrm{YN}$ & Ariège & Neg. & - & $>40$ & - & $>40$ & - & $>40$ & + & $15.2(0.2)$ \\
\hline 08-764-3' & $\mathrm{YN}$ & Ariège & Neg. & - & $>40$ & - & $>40$ & - & $>40$ & + & $14.9(0.1)$ \\
\hline 08-764-4' & $\mathrm{YN}$ & Ariège & Neg. & - & $>40$ & - & $>40$ & - & $>40$ & + & $14.9(0.2)$ \\
\hline 08-792 & YN & Ariège & Neg. & - & $36.5(0.6)^{\mathrm{e}}$ & - & $36.3(1.5)^{\mathrm{e}}$ & - & $>40$ & + & $19.4(0.6)$ \\
\hline $08-863-1$ & $\mathrm{YN}+\mathrm{BS}+$ Pyc. & Pyrénées atlantiques & L. acicola & $+^{\mathrm{e}}$ & $19.9(0.2)^{\mathrm{e}}$ & - & $>40$ & - & $>40$ & + & $14.8(0.2)$ \\
\hline $08-863-2$ & $\mathrm{YN}+\mathrm{BS}+\mathrm{Pyc}$ & Pyrénées atlantiques & L. acicola & $+^{\mathrm{e}}$ & $19.5(0.1)^{\mathrm{e}}$ & - & $>40$ & - & $>40$ & + & $17.0(0.1)$ \\
\hline 08-1010 & YN + BS + Pyc. & Landes & L. acicola & $+^{\mathrm{e}}$ & $22.5(0.0)^{\mathrm{e}}$ & - & $>40$ & - & $>40$ & + & $16.3(0.4)$ \\
\hline 08-1011 & $\mathrm{YN}+\mathrm{BS}$ & Pyrénées atlantiques & Neg. & - & $>40$ & - & $>40$ & - & $>40$ & + & $13.7(0.2)$ \\
\hline 08-1066 & $\mathrm{YN}+\mathrm{BS}$ & Pyrénées atlantiques & Neg. & - & $>40$ & - & $>40$ & $t^{e}$ & $26.7(0.1)^{\mathrm{e}}$ & + & $15.0(0.3)$ \\
\hline $08-1160$ & YN & Pyrénées orientales & Neg. & - & $>40$ & - & $>40$ & - & $>40$ & + & $14.9(0.2)$ \\
\hline 08-1174 & YN + BS + Pyc. & Pyrénées atlantiques & L. acicola & $+^{\mathrm{e}}$ & $20.7(0.0)^{\mathrm{e}}$ & - & $>40$ & - & $>40$ & + & $13.3(0.1)$ \\
\hline 081456-1 & $\mathrm{YN}+\mathrm{RB}+$ Pyc. & Ille et Vilaine & Dothistroma sp. & - & $>40$ & + & $26.4(0.1)$ & - & $>40$ & + & $17.5(0.1)$ \\
\hline 081456-2 & $\mathrm{YN}+\mathrm{RB}+$ Pyc. & Ille et Vilaine & Dothistroma sp. & - & $>40$ & + & $26.3(0.1)$ & - & $>40$ & + & $17.3(0.0)$ \\
\hline $08-1480$ & $\mathrm{YN}+\mathrm{RB}+$ Pyc. & Aisne & Dothistroma sp. & - & $>40$ & + & $28.7(0.2)$ & - & $>40$ & + & $17.0(0.3)$ \\
\hline $08-1521$ & $\mathrm{YN}+\mathrm{RB}+$ Pyc. & Pyrénées atlantiques & Neg. & - & $>40$ & $+^{e}$ & $29.2(0.0)^{\mathrm{e}}$ & $+^{e}$ & $26.8(0.1)^{\mathrm{e}}$ & + & $18.1(0.1)$ \\
\hline $08-1548$ & $\mathrm{YN}+\mathrm{RB}+$ Pyc. & Tarn et Garonne & Dothistroma sp. & - & $>40$ & - & $>40$ & $+^{e}$ & $31.6(1.0)^{\mathrm{e}}$ & + & $16.4(0.5)$ \\
\hline 4747363 & $\mathrm{YN}+\mathrm{RB}$ & The Netherlands & Dothistroma sp. & - & $>40$ & $+^{e}$ & $26.0(0.1)^{\mathrm{e}}$ & - & $>40$ & + & $20.8(0.0)$ \\
\hline 4747381 & $\mathrm{YN}+\mathrm{RB}$ & The Netherlands & Dothistroma sp. & - & $>40$ & + & $25.4(0.1)$ & - & $>40$ & + & $20.4(0.1)$ \\
\hline B08572/Myc & $\mathrm{YN}+\mathrm{RB}$ & Belgium (Wallonia) & Neg. & - & $>40$ & $+^{e}$ & $30.1(0.8)^{\mathrm{e}}$ & - & $>40$ & + & $13.8(0.1)$ \\
\hline
\end{tabular}

${ }^{a} \mathrm{YN}=$ yellowing needles, $\mathrm{RB}=$ red bands, $\mathrm{Pyc}=$ pycnidia, and $\mathrm{BS}=$ brown spots.

${ }^{\mathrm{b}}$ Neg. = sample for which no typical Dothistroma pini, D. septosporum, or L. acicola conidia could be observed.

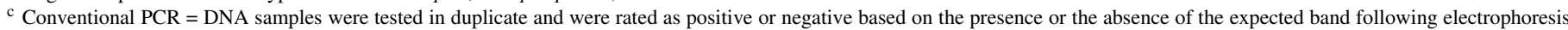
of the conventional PCR product; real-time PCR = cycle thresholds were computed with each DNA sample tested in triplicate. Standard deviation is indicated between parentheses; n.a. $=$ nonamplifiable.

${ }^{\mathrm{d}}$ ITS = internal transcribed spacer. Quality of the DNA extract was assessed in conventional PCR using universal fungal PCR primers (21).

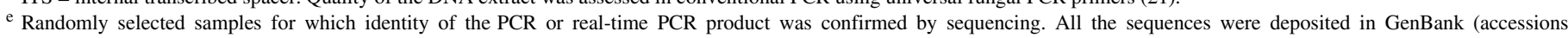
FJ868500-FJ868556). 
son of the detection tools, and all the sequences were deposited in GenBank (Table 5). BLAST analyses of the sequences showed that $100 \%$ of the sequences corresponded to the expected target species.

\section{DISCUSSION}

During this work, a set of new tools for the molecular detection of the brown spot and red band needle blight pathogens was developed using intronic regions of the $\beta$-tub2 (D. septosporum) and EF1- $\alpha$ (D. pini and L. acicola) genes, which contain sufficient interspecific but no intraspecific polymorphisms.

The experimental specificity of the PCR assays was demonstrated by sequencing the PCR products obtained with a large set of naturally infected samples and isolating the pathogens from a subset of the samples. Because our study used naturally infected samples, we did not determine the diagnostic sensitivity of the tests. However, DLP real-time PCR proved to be significantly more sensitive than the humid chamber test that is one of the recommended methods for routine detection of the pathogen (8). The PCR tests had two other significant advantages over the humid chamber analysis because it enabled the detection of the two Dothistroma spp. on needles without conidiomata-or without mature conidiomata-and could also differentiate infections by $D$. pini from infections by $D$. septosporum. To our knowledge, although no molecular test is available for the detection of $L$. acicola, two molecular tests have been described in the literature for $D$. pini and D. septosporum. Barnes et al. (4) developed a PCR-RFLP procedure to distinguish $D$. pini from $D$. septosporum but this test requires a prior isolation of the fungus in pure culture. Groenewald et al. (11) recently designed two couples of matingtype-specific PCR primers which were shown to be specific for $D$. pini or D. septosporum, respectively, and can be used in a duplex PCR reaction, and Barnes et al. (3) developed a series of microsatellite primers that could potentially be used for species discrimination. Unfortunately, these primers were not yet assessed for in planta detection and no analytical sensitivity data was provided.

In the present study, although conventional PCR showed equivalent ability to detect the three pathogens in naturally infected needles samples, the more practical technique was the multiplex DLP real-time assay targeting D. pini, D. septosporum, and $L$. acicola simultaneously. This assay also included a primer/ probe combination that targeted a highly conserved region of rDNA, which serves as an internal DNA quality control and limits the risk of false negatives that may occur when testing environmental samples by PCR as a result of PCR inhibition or insufficient DNA quality or quantity $(13,22)$.

Compared with conventional PCR, real-time PCR is faster and less prone to cross- and self-contamination, because the tubes are kept closed after the amplification and no post-amplification processing steps are required. The use of species-specific probes also provides additional specificity to the real-time tests. In this study, the real-time PCR tools showed a lower analytical sensitivity than conventional PCR, and the quadruplex DLP real-time PCR assay was demonstrated to be more sensitive and versatile than the DSP real-time PCR assay, although the same locus was targeted. The herein-described multiplex DLP real-time protocol makes it possible to detect each of the three pathogens in a single tube without apparent loss of sensitivity and with a smaller cost than separate monoplex assays. In addition, the ability to prepare and store ready-to-use stock solutions of premixed primers and DLP makes the real-time PCR mastermix preparation straightforward and minimizes the risk of pipetting errors.

Stem-loop scorpion probes have already been developed for a few fungal plant pathogens $(15,17)$ and were shown to be more sensitive than conventional PCR assays. This study compared an improved generation of scorpion probes using a duplex format with another real-time chemistry, such as DLP, and with conventional PCR, all targeting the same loci. DSP was found to be less sensitive than hydrolysis probes, based upon the experimental detection threshold that was determined with pure fungal DNA. This observation correlates with similar experiments that involved similar real-time chemistries that targeted the plant pathogen Phytophthora ramorum (20). However, the DSP assay was judged to be as sensitive as the DLP assay with the set of naturally infected samples we tested. Unlike DLP real-time PCR systems, the DSP format is not dependent on enzymatic cleavage and, therefore, rapid PCR cycling is possible. Rapid cycling conditions were successfully tested with the DSP described herein, which reduced the turnaround time by a factor of two (R. Ioos, unpublished data).

For diagnosis laboratories that are not yet equipped with realtime PCR devices, conventional PCR using the species-specific PCR primers described here may still be a good alternative, because they proved to be specific and offered sufficient sensitivity to detect the target pathogen, although sensitivity was slightly lower than the DLP test. Although this study only used individual standardized samples consisting of 5 needle pieces each, samples prepared with up to 10 to 15 symptomatic needle pieces in a single tube can still be routinely processed, and this may partially alleviate the lower sensitivity of conventional PCR.

Several DNA extraction procedures, which started from symptomatic needles, were also evaluated. In this study, the CTAB/ phenol-chloroform DNA extraction was found to be unsuitable to recover amplifiable fungal DNA starting from infected needles, probably due to the co-extraction of PCR-inhibiting compounds. The four commercial DNA extraction kits that were assessed all proved efficient in their ability to produce high-quality fungal DNA, although slight, significant differences were observed. This contrasts with previous findings of significant differences between commercial DNA extraction kits for the detection of

TABLE 6. Discrepant analysis result of environmental needle samples by real-time polymerase chain reaction (PCR), conventional PCR, and humid chamber ${ }^{\mathrm{a}}$

\begin{tabular}{|c|c|c|c|c|c|}
\hline Target fungus & Real-time PCR & Conventional PCR & Humid chamber & No. of samples & Samples $(\%)$ \\
\hline \multirow[t]{5}{*}{ Dothistroma septosporum/D. pini } & + & + & + & 21 & 44.7 \\
\hline & + & + & - & 9 & 19.1 \\
\hline & + & n.a. & + & 1 & 2.1 \\
\hline & + & - & - & 2 & 4.3 \\
\hline & - & - & - & 13 & 27.7 \\
\hline Total & & & & 47 & 100.0 \\
\hline \multirow[t]{3}{*}{ Lecanosticta acicola } & + & + & + & 5 & 10.7 \\
\hline & + & - & - & 1 & 2.1 \\
\hline & - & - & - & 39 & 83.0 \\
\hline Total & & & & 47 & 100.0 \\
\hline
\end{tabular}

${ }^{a}$ n.a. $=$ Nonamplifiable. 
Fusarium circinatum in Pinus seed (14) or Puccinia horiana in Chrysanthemum leaves (1). This, therefore, indicates that such a comparison should be carried out for each matrix/pathogen couple.

In this study, analysis by DLP real-time PCR of naturally infected samples collected across France also offered a new insight of the raw geographical distribution of the studied pathogens. D. pini was so far only reported in the United States, Ukraine, and Russia (5). This study demonstrated that this newly described species has a widespread presence in France. Because previously used methods such as the humid chamber fail to differentiate $D$. pini from $D$. septosporum, the current distribution of this pathogen in Europe might be much larger than previously thought. In addition, our PCR results showed that two of the three target species could be simultaneously detected in a single needle subsample. Surprisingly, D. pini was also detected from two needle samples with brown spot symptoms, more typical of the presence of $L$. acicola. These results support the need to resort to specific molecular techniques to investigate the prevalence of all three pathogens in different parts of the world as well as to improve the knowledge about their epidemiology. These aspects are particularly important, because all three pathogens are regarded as quarantine fungi for numerous plant protection organizations throughout the world.

\section{ACKNOWLEDGMENTS}

This research was supported financially by the Direction Générale de l'Alimentation, Sous Direction de la Qualité et de la Protection des Végétaux (Ministry of Agriculture, France), INRA, and ANR (EMERFUNDIS Program ANR 07-BDIV-003). We thank the Département de la Santé des Forêts for the collection of the samples used in this study and the Senior Editor of Phytopathology and two anonymous reviewers for their helpful comments on this manuscript.

\section{LITERATURE CITED}

1. Alaei, H., Baeyen, S., Maes, M., Höfte, M., and Heungens, K. 2009. Molecular detection of Puccinia horiana in Chrysanthemum $\times$ morifolium through conventional and real-time PCR. J. Microbiol. Methods 76:136145.

2. Anonymous. 2000. Council Directive 2000/29/EC of 8 May 2000 on protective measures against the introduction into the Community of organisms harmful to plants or plant products and against their spread within the Community. O.J.L 169, 10.7.2000:1.

3. Barnes, I., Cortinas, M. N., Wingfield, M. J., and Wingfield, B. D. 2008. Microsatellite markers for the red band needle blight pathogen, Dothistroma septosporum. Mol. Ecol. Resour. 8:1026-1029.

4. Barnes, I., Crous, P. W., Wingfield, B. D., and Wingfield, M. J. 2004. Multigene phylogenies reveal that red band needle blight of Pinus is caused by two distinct species of Dothistroma, D. septosporum and D. pini. Stud. Mycol. 50:551-565.

5. Barnes, I., Kirisits, T., Akulov, A., Chhetri, D. B., Wingfield, B. D., Bulgakov, T. S., and Wingfield, M. J. 2008. New host and country records of the Dothistroma needle blight pathogens from Europe and Asia. For. Pathol. 38:178-195.

6. Bustin, S. 2000. Absolute quantification of mRNA using real-time reverse transcription polymerase chain reaction assays. J. Mol. Endocrinol. 25:169-193.

7. Carbone, I., and Kohn, L. 1999. A method for designing primer sets for speciation studies in filamentous ascomycetes. Mycologia 91:553-556.

8. EPPO. 2008. Mycosphaerella dearnessii and Mycosphaerella pini. EPPO Bull. 38:349-362.

9. Evans, H. C. 1984. The genus Mycosphaererella and its anamorphs Cercoseptoria, Dothistroma and Lecanosticta on pines. Mycol. Pap. 153:1-102.

10. Glass, N., and Donaldson, G. 1995. Development of primer sets designed for use with the PCR to amplify conserved genes from filamentous ascomycetes. Appl. Environ. Microbiol. 61:1323-1330.

11. Groenewald, M., Barnes, I., Bradshaw, R. E., Brown, A. V., Dale, A., Groenewald, J. Z., Lewis, K. J., Wingfield, B. D., Wingfield, M. J., and Crous, P. W. 2007. Characterization and distribution of mating type genes in the Dothistroma needle blight pathogens. Phytopathology 97:825-834.

12. Henrion, B., Chevalier, G., and Martin, F. 1994. Typing truffle species by PCR amplification of the ribosomal DNA spacers. Mycol. Res. 98:37-43.

13. Hoorfar, J., Malorny, B., Abdulmawjood, A., Cook, N., Wagner, M., and Fach, P. 2004. Practical considerations in design of internal amplification controls for diagnostic PCR assays. J. Clin. Microbiol. 42:1863-1868.

14. Ioos, R., Fourrier, C., Iancu, G., and Gordon, T. R. 2009. Sensitive detection of Fusarium circinatum in pine seed by combining an enrichment procedure with a real-time polymerase chain reaction using duallabeled probe chemistry. Phytopathology 99:582-590.

15. Ippolito, A., Shena, L., Nigro, F., Ligorio, V. S., and Yaseen, T. 2004. Real-time detection of Phytophthora nicotianae and P. citrophthora in citrus roots and soil. Eur. J. Plant Pathol. 110:833-843.

16. Schena, L., Hughes, K. J. D., and Cooke, D. E. L. 2006. Detection and quantification of Phytophthora ramorum, $P$. kernoviae, $P$. citricola and $P$. quercina in symptomatic leaves by multiplex real-time PCR. Mol. Plant Pathol. 7:365-379.

17. Schena, L., Nigro, F., and Ippolito, A. 2002. Identification and detection of Rosellinia necatrix by conventional and real-time Scorpion-PCR. Eur. J. Plant Pathol. 108:355-366.

18. Sieber, T. N., Rys, J., and Holdenrieder, O. 1999. Mycobiota in symptomless needles of Pinus mugo ssp. uncinata. Mycol. Res. 103:306-310.

19. Solinas, A., Brown, L. J., McKeen, C., Mellor, J. M., Nicol, J., Thelwell, N., and Brown, T. 2001. Duplex Scorpion primers in SNP analysis and FRET applications. Nucleic Acids Res. 29:e96.

20. Tomlinson, J. A., Barker, I., and Boonham, N. 2007. Faster, simpler, more-specific methods for improved molecular detection of Phytophthora ramorum in the field. Appl. Environ. Microbiol. 73:4040-4047.

21. White, T. J., T. D. Bruns, S. B. Lee, and J. W. Taylor. 1990. Amplification and direct sequencing of fungal ribosomal RNA Genes for phylogenetics. Pages 315-322 in: PCR-Protocols and Applications-A Laboratory Manual. D. G. N. Innis, J.Sninsky, and T. White, eds. Academic Press, New York.

22. Wilson, I. 1997. Inhibition and facilitation of nucleic acid amplification. Appl. Environ. Microbiol. 63:3741-3751. 